(C) 2018 by the Arizona Board of Regents on behalf of the University of Arizona. This is an Open Access article, distributed under the terms of the Creative Commons Attribution-NonCommercial-ShareAlike licence (http://creativecommons.org/licenses/by-ncsa/4.0/), which permits non-commercial re-use, distribution, and reproduction in any medium, provided the same Creative Commons licence is included and the original work is properly cited. The written permission of Cambridge University Press must be obtained for commercial re-use.

\title{
SELECTIVE DATING OF PAINT COMPONENTS: RADIOCARBON DATING OF LEAD WHITE PIGMENT
}

\author{
Laura Hendriks $^{1} \cdot$ Irka Hajdas $^{1 *} \cdot$ Ester S B Ferreira $^{2} \cdot$ Nadim C Scherrer $^{3} \bullet$ \\ Stefan Zumbühl ${ }^{3} \cdot$ Markus Küffner $^{4} \cdot$ Leslie Carlyle $^{5} \cdot$ Hans-Arno Synal $^{1} \cdot$ Detlef Günther $^{6}$ \\ ${ }^{1}$ Laboratory of Ion Beam Physics, ETH-Zürich, Otto-Stern-Weg 5, 8093 Zurich, Switzerland. \\ ${ }^{2}$ CICS - Cologne Institute of Conservation Sciences, TH Köln, University of Applied Sciences, Campus Südstadt, \\ Ubierring 40, 50678 Köln, Germany. \\ ${ }^{3}$ HKB - Bern University of Applied Sciences, Fellerstrasse 11, 3027 Bern, Switzerland. \\ ${ }^{4}$ SIK-ISEA - Swiss Institute for Art Research, Zollikerstrasse 32, 8032 Zurich, Switzerland. \\ ${ }^{5}$ NOVA - New University of Lisbon, Department of Conservation \& Restoration, Faculty of Sciences and \\ Technology, Caparica Campus, Caparica 2829-516, Portugal. \\ ${ }^{6}$ Laboratory of Inorganic Chemistry, ETH Zürich, Vladimir-Prelog-Weg 1-5/10, 8093 Zürich, Switzerland.
}

\begin{abstract}
Lead white is a man-made white pigment commonly used in works of art. In this study, the possibility of radiocarbon dating lead white pigments alone and in oil paints was explored using well-dated lead white pigments and paints. Resulting ${ }^{14} \mathrm{C}$ ages on lead white pigments produced following the traditional stack process, where carbonate groups results from the incorporation of $\mathrm{CO}_{2}$ originating from fermentation, matched the production years, while radiocarbon dating of lead white made using other industrial processes indicate that ${ }^{14} \mathrm{C}$ depleted $\mathrm{CO}_{2}$ was used in their production. The method was applied to two case studies, where lead carbonate samples were dated in two oil paintings, one Baroque and one from the 20th century. We hereby show that the lead white pigment can be dated by ${ }^{14} \mathrm{C}$ and used as proxy for the time of creation of an artwork. Additionally, a two-step method was developed to allow ${ }^{14} \mathrm{C}$ analysis of both the lead white pigment and oil binder from the same sample. A single lead white paint sample can yield two distinct radiocarbon ages, one from the carbonate and one from the natural organic binder. This study thus proposes new strategies for ${ }^{14} \mathrm{C}$ dating of artworks.
\end{abstract}

KEYWORDS: carbonates, lead white, micro-sampling, paintings, pigment, radiocarbon dating, stack process.

\section{INTRODUCTION}

Lead white, a basic lead carbonate, has been the most extensively used white pigment by artists since Antiquity up to the 20th century, when it was gradually replaced with less toxic white pigments. Beside the basic lead carbonate "hydrocerussite" $\mathrm{Pb}_{3}\left(\mathrm{CO}_{3}\right)_{2}(\mathrm{OH})_{2}$, also "Cerussite" $\mathrm{Pb}\left[\mathrm{CO}_{3}\right]$ as well as "plumbonacrite" $\mathrm{Pb}_{5}\left(\mathrm{CO}_{3}\right)_{3} \mathrm{O}(\mathrm{OH})_{2}$ can be found in paintings. This manmade white pigment may be used in the ground or paint layer, pure or admixed with other pigments and additives. In addition, it possesses the advantage of accelerating the oil drying process. Up until the 19th century lead white was the most important white pigment in the art market. In the 18th century, zinc oxide was discovered as an alternative white pigment, however this one only became a real competitor to lead white in the 19th century (Roy 1993). Lead white can therefore still be found in early 20th century paintings, when its use declined as its manufacture and sale was first restricted, and then forbidden due to its toxicity. The introduction of titanium white during the 20th century meant that lead white was no longer as central to the artist's palette (Eastaugh 2008). Because of its widespread use throughout history, lead white pigments has been of limited use for the study and dating of works of art. In the course of authentication research, lead white had its moment of glory as its isotopic signature supported the attribution of a Vermeer painting (Ragai 2015). Indeed isotopic analyses of lead white can be used as a fingerprint to trace the origin of the pigment and thereby provide compelling

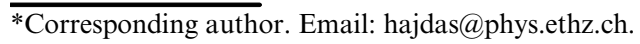


evidence regarding the whereabouts of a painting's creation (Fortunato et al. 2005). In the field of authentication, lead isotopes abundance ratios can thus be used to identify the origin, but no information can be gained regarding the age of the pigment and therefore the object.

Recent developments in accelerator mass spectrometry (AMS), in particular, with respect to sample size downscaling, have allowed the application scale of radiocarbon dating to be widened, in particular to cultural heritage studies (Fedi et al. 2013; Caforio et al. 2014; Hendriks et al. 2016; Petrucci et al. 2016). In most cases, only the support material is sampled, yet the respective radiocarbon results may be misleading, as the support may be older than the actual painting itself, e.g. in cases where old supports have been reused by artists themselves or by forgers. In the search for other candidates suitable for ${ }^{14} \mathrm{C}$ analysis, the natural organic oil binder was found to be ideal (Hendriks et al. 2018). Indeed, the ${ }^{14} \mathrm{C}$ clock of natural drying oils initiates with the harvesting of the seeds from which the oil is extracted, hence dating of the oil is very likely to be representative of the time of creation of the paint. However, an offset in the age may also be observed, since artists prized aged oil, which could be kept for long periods before being used to make paint (Carlyle 2001b).

With the help of radiocarbon analysis, similarly to in-situ formed calcium carbonate in the dating of lime mortars (Ringbom et al. 2014 and references therein), lead white can be used as proxy for the time of creation of an object. Indeed, the ${ }^{14} \mathrm{C}$ signature of the carbonate anion is related to the pigment's production process and its respective date of production. The idea of using lead white as a time proxy was demonstrated by Van Strydonck and co-workers in a recent work regarding the dating of a corpse found in a lead coffin (Van Strydonck et al. 2016). In their study, the lead carbonate crust that formed on the bottom inside the lead coffin was dated and allowed to establish the time of death of the corpse in the coffin. Their approach was based on the assumption that the lead carbonate was formed by the reaction of $\mathrm{CO}_{2}$ emitted from the putrefying corpse. Hence the ${ }^{14} \mathrm{C} /{ }^{12} \mathrm{C}$ ratio of the carbonate reflected the ${ }^{14} \mathrm{C} /{ }^{12} \mathrm{C}$ of the body inside the coffin and henceforth the respective time of death.

This particular study was driven by the omnipresence of lead white in oil paintings by Franz Rederer (1899-1965) and the need to eliminate it. By treating the sample with acid and converting the lead carbonate to a carbon free inorganic fraction by release of $\mathrm{CO}_{2}$ the ${ }^{14} \mathrm{C}$ dating of the organic binder was made possible (Hendriks et al. 2018). The work presented herein introduces the possibility of using ${ }^{14} \mathrm{C}$ analysis for the dating of the lead white pigment itself. Due to the many different recipes, the sources of carbon dioxide have evolved and the respective ${ }^{14} \mathrm{C}$ signature will reflect either atmospheric ${ }^{14} \mathrm{C}$ level or fossil derived sources. One of the most critical issues in the ${ }^{14} \mathrm{C}$ dating of artworks is the sampling step. The invasiveness of the method limits its application and hence we demonstrate the additional possibility to date the oil remaining in the sample after the carbonate decomposition. By demonstrating the feasibility of radiocarbon dating the lead white pigment and, additionally, the organic binder from the same sample in a two-step preparation process, the potential of the ${ }^{14} \mathrm{C}$ analysis comes into balance with the sacrifice of taking a sample. We hereby propose new candidates for ${ }^{14} \mathrm{C}$ dating of a painting, as alternatives or complementary to the support material.

\section{LEAD WHITE PRODUCTION}

Lead white may be produced following many different processes. The traditional stack (or Dutch) process involves the exposure of strips of metallic lead to acetic acid and fermenting organic material, the latter of which provides both heat and a higher concentration of carbon dioxide. Over several weeks the combined action of air, acetic acid, and carbon dioxide 
successively converts the metallic lead to lead hydroxide, lead acetate basic lead acetate, and finally to lead carbonate hydroxide (see Equations 1-4) (Sharma 1991), commonly known in artist jargon as basic lead white. Many patents and variations of the process have been published, the most popular being the stack or Dutch process, where metallic lead is placed in ceramic pots and the floor of the chamber is covered with manure. This process knew very little alteration in the 18th century and was the most common way of producing lead white pigment until the end of the 19th century. However, more efficient means were explored. In 1749 James Creed patented the so-called chamber method, where the innovation was to supply heated gas to the chamber (Eastaugh 2008). The patent describes how the use of organic fermenting material could be negated by using the heat of fire. Whether Creed fully understood the chemical process taking place is unclear, as the existence of carbon dioxide was only discovered in the late 18th century and was referred to as "fixed air". Some years later in Germany, a new turn in the production of lead white occurred. Near Klagenfurt, the family factory of Herbert was renowned for producing lead white of excellent quality (Sedlacek 1938). Herbert implemented the Dutch process to his advantage, using fruit must vinegar from his own orchard as raw starting material, supplying the reaction with the necessary gases and vapors. His success gave way to the construction of a second factory in 1792, which was the first to implement the so-called German process. This practice was first described by Gustav Dietel in 1839 in Eisenach, where a charcoal-heated furnace was coupled to the chambers to provide more heat and a constant carbon dioxide stream. This process was continuously adapted and by the beginning of the 19th century could be found in most of Europe under different names, such as the French process in France or the Rowe process in the United Kingdom. In the 19th century the number of new processes flourished thanks to the development of industrialization and modern chemistry. The metallic lead could be exposed in a dry environment or immersed in water and the final product was achieved by precipitation or electrolysis. A short review for the different preparation processes described above can be found in Pérez-Villares and Bailón-Moreno (2017), while an extensive review was written by Stols-Witlox (Stols-Witlox et al. 2012).

In many cases, natural and industrially synthesized pigments can be differentiated based on the presence/absence of byproducts/contaminants. For example, the pigment ultramarine blue is nowadays artificially synthesized but it used to be based on the mineral lazurite extracted from Lapis Lazuli. There are several ways of distinguishing lazurite from synthetic ultramarine, for example based on their elemental composition and the identification of specific mineral phases (Favaro et al. 2012). In the case of lead white, although particle morphology analysis by scanning electron microscopy does point to a clear difference between the traditional method versus the modern, no dating information can be gained. Radiocarbon, however, has the power not only to discriminate between production processes but can also give a time range. In order to date lead white pigment, the specific source of carbon dioxide used in the formation of the carbonate anion (see Equation 3) is of interest.

$$
\begin{gathered}
2 \mathrm{~Pb}+\mathrm{O}_{2}+2 \mathrm{H}_{2} \mathrm{O} \rightarrow 2 \mathrm{~Pb}(\mathrm{OH})_{2} \\
\mathrm{~Pb}(\mathrm{OH})_{2}+2 \mathrm{CH}_{3} \mathrm{COOH} \rightarrow \mathrm{Pb}\left(\mathrm{CH}_{3} \mathrm{COO}\right)_{2}+2 \mathrm{H}_{2} \mathrm{O} \\
\mathrm{Pb}\left(\mathrm{CH}_{3} \mathrm{COO}\right)_{2}+2 \mathrm{~Pb}(\mathrm{OH})_{2} \rightarrow \mathrm{Pb}\left(\mathrm{CH}_{3} \mathrm{COO}\right)_{2} \cdot 2 \mathrm{~Pb}(\mathrm{OH})_{2} \\
\mathrm{~Pb}\left(\mathrm{CH}_{3} \mathrm{COO}\right)_{2} \cdot 2 \mathrm{~Pb}(\mathrm{OH})_{2}+\mathrm{CO}_{2} \rightarrow \mathrm{Pb}\left(\mathrm{CH}_{3} \mathrm{COO}\right)_{2}+\mathrm{PbCO}_{3} \cdot \mathrm{Pb}(\mathrm{OH})_{2}+\mathrm{H}_{2} \mathrm{O}
\end{gathered}
$$

When $\mathrm{CO}_{2}$ is produced from fermenting organic material as described in the stack process, the carbonate will carry the ${ }^{14} \mathrm{C}$ signature of the atmosphere and can be used for dating the time of 
production. With the advent of the alternative methods, such as the chamber process, the carbon dioxide source varied considerably from coal fires to the addition of calcium carbonate or potassium carbonate to vinegar (Eastaugh 2008). The ${ }^{14} \mathrm{C}$ signature of carbon dioxide was thus radically changed as in such material the ${ }^{14} \mathrm{C}$ content is very low and resulting ${ }^{14} \mathrm{C}$ ages are more than thousands of years old. As a result, lead white issued from industrial production cannot per se be dated but can be used as a marker for identifying lead white made with alternative methods to the traditional stack process.

\section{MATERIALS}

\section{Reference Material}

\section{Lead White Pigment and Oil Paint Samples}

Two different sources of lead white pigment, both presumably prepared using modern methods, were provided from the MOLART Fellowship 1999 reference collection ${ }^{1}$ (Carlyle 2001a; Carlyle 2005): one which had been prepared commercially in the 20th century by the Schoonhoven Company ${ }^{2}$, and the second, which had been purchased from Kremer Pigmente. Lead white pigments made following the Dutch/Stack Process had been prepared in separate batches between 2002 and 2005 for the HART project ${ }^{1}$. Samples with creation dates were provided from the HART project reference collection (Table 2) and consisted of both washed and unwashed lead white pigment (washing was carried out with Millipore water, see Carlyle (2005)). Oil paint samples were also provided from the MOLART and HART reference collections. In both cases the oil had been extracted from linseeds purchased for the projects (Electra linseed seeds from Flevo Vlas Loonwerk B.V obtained in 1999 and 2005).

\section{Paint Reconstructions}

In order to assess if the method developed for measuring ${ }^{14} \mathrm{C}$ ages of the lead carbonate within the paint matrix successfully eliminated the interference of the binder, a series of lead white oil paint reconstructions of different origin and date were tested (Table 2).

In a second step, the possibility of dating the oil binder residue after the carbonate decomposition was pursued. Various organic solvents (see Table 1) were tested to optimize the extraction of the organic phase. Preliminary studies were conducted on paint of known composition, namely a mixture of umber pigment and chalk $\left(\mathrm{CaCO}_{3}\right)$. Additionally, from the SIKISEA collection, lead white paint prepared in 1981 was tested for sequential carbonate and oil dating. Paint reconstructions from both the MOLART and HART projects were also used (Table 2).

\footnotetext{
${ }^{1}$ The MOLART Fellowship was carried out by Carlyle in 1999 (Carlyle, MOLART Fellowship Report 2001) as part of the MOLART project, Molecular Aspects of Ageing in Painted Works of Art (1995-2002), directed by Professor Dr Jaap Boon, funded by the Netherlands Organisation for Scientific research (NWO). The HART project, Historically Accurate Oil Painting Reconstruction Techniques (2002 to 2005), was part of the De Mayerne Programme led by Professor Dr Jaap Boon and funded by the Netherlands Organisation for Scientific Research (NWO). Carlyle was Principle Investigator (PI) for the HART Project (Carlyle, HART Project Report, 2005), which was hosted by the Netherlands Institute of Cultural Heritage (ICN) and supported by the Netherlands Institute for Atomic and Molecular Physics (FOM-AMOLF) and the Canadian Conservation Institute (CCI).

${ }^{2}$ One of the lead white pigments used in the MOLART Fellowship had been purchased by Karin Groen (ICN) likely in the late 1990s, from the windmill De Kat in Zaandam, NL. Dr Groen was informed that it was the last batch they had from the Schoonhoven Company, which they said had been the last of the stack lead white manufacturers in the Netherlands when it closed in 1989. Groen presumed it was made by the Dutch Stack Process, but later investigation by Katrien Keune with the scanning electron microscope (SEM) during the De Mayerne Programme (see above) strongly suggested that was produced with a modern technique due to its particle morphology (see Carlyle, HART Project Report, 2005).
} 
Table 1 Solvents tested for the organic phase extraction.

\begin{tabular}{|c|c|c|c|c|c|c|}
\hline Solvent & $\begin{array}{l}\text { Chemical } \\
\text { formula }\end{array}$ & $\begin{array}{l}\mathrm{MW} \\
\text { (g/ } \\
\mathrm{mol})\end{array}$ & Density & $\begin{array}{l}\text { Purity } \\
(\%)\end{array}$ & $\begin{array}{l}\text { Vapor pressure } \\
(\mathrm{kPa}) 20^{\circ} \mathrm{C}\end{array}$ & Supplier \\
\hline Dichloromethane & $\mathrm{CH}_{2} \mathrm{Cl}_{2}$ & 84.93 & 1.325 & $>99.9$ & 45.3 & $\begin{array}{l}\text { Honeywell, Morristown, } \\
\text { New Jersey, USA }\end{array}$ \\
\hline Diethyl ether & $\left(\mathrm{C}_{2} \mathrm{H}_{5}\right)_{2} \mathrm{O}$ & 74.12 & 0.902 & $>99.91$ & 58.7 & $\begin{array}{l}\text { Fischer chemical, Zurich, } \\
\text { Switzerland }\end{array}$ \\
\hline Hexane & $\mathrm{C}_{6} \mathrm{H}_{14}$ & 86.18 & 0.659 & $>95$ & 16.0 & $\begin{array}{l}\text { Sigma Aldrich, St. Louis, } \\
\text { Missouri, USA }\end{array}$ \\
\hline Ethyl acetate & $\mathrm{C}_{4} \mathrm{H}_{8} \mathrm{O}_{2}$ & 88.11 & 0.902 & $>99.5$ & 10.0 & $\begin{array}{l}\text { Honeywell, Morristown, } \\
\text { New Jersey, USA }\end{array}$ \\
\hline Toluene & $\mathrm{C}_{7} \mathrm{H}_{8}$ & 92.14 & 0.867 & 100 & 3.8 & $\begin{array}{l}\text { VWR chemicals, Radnor } \\
\text { Pennsylvania, USA }\end{array}$ \\
\hline Chloroform & $\mathrm{CHCl}_{3}$ & 119.38 & 1.48 & $>99.8$ & 21.1 & $\begin{array}{l}\text { Merck Millipore, } \\
\text { Darmstadt, Germany }\end{array}$ \\
\hline
\end{tabular}

\section{Case Studies}

Among the objects made available for the study was an oil on canvas painting by Franz Rederer (1899-1965) entitled Bildnis Margrit mit roter Jacke und Konzertkleid, 1962, $140 \times 100$ cm, SIKISEA, Zurich (Figure 1). The results of the radiocarbon dating of the canvas and oil binder from this panting has been previously reported (Hendriks et al. 2018). For this study, a sample of green paint from the reverse of the canvas was collected. Being unvarnished and never having been restored, the material from this painting presents ideal case study material as no new sources of carbon have been added. The green paint was known to bear some lead white pigment and provided therefore fitting material for the subsequent dating of the oil after the carbonate decomposition.

An additional oil on canvas painting unattributed and with no signed date, shown in Figure 2, also belonging to the SIK-ISEA collection, was sampled for lead white containing paint and analyzed. Based on stylistic assessment the painting of the half-length female portrait is estimated to be around the 17th century. Thanks to fashion details a time of origin can be assessed, indeed the high headdress, also known as Fontange, was very popular in the period $1685-1715^{3}$. The canvas and brown paint were also sampled, to compare the lead white radiocarbon age with the ages of the support and organic binder. A more detailed overview of the sampling location is given in Figure 1 and Figure 2.

\section{METHOD}

\section{Analytical Techniques for Paint Characterization of the Two Case Studies}

Suitable paint locations bearing lead white were identified and characterized by combining X-ray fluorescence (XRF), Fourier-transform infrared (FTIR), and Raman spectroscopy. The XRF study was conducted with a Bruker AXS ARTAX 800 system equipped with a Rh target (Bruker, Karlsruhe, Germany). The XRF spectra were acquired using the following parameters: excitation spot $<100 \mu \mathrm{m}$, generator voltage $50 \mathrm{kV}$, current $600 \mu \mathrm{A}$, helium atmosphere, and acquisition time $100 \mathrm{~s}$. Paint locations, which showed intense $\mathrm{Pb}$ signals, were sampled

\footnotetext{
${ }^{3}$ Gretel Wagner, Fontange. In: Reallexikon zur Deutschen Kunstgeschichte, Bd. X (2004), Sp. 184-189; in: RDK Labor, URL: <http://www.rdklabor.de/w/?oldid=89118> [14.03.2018]
} 
Table 2 Overview of the reference sample material used in this study. The extraction date of the oil from the seeds is irrelevant for ${ }^{14} \mathrm{C}$ analysis, as the process will not impact the ${ }^{14} \mathrm{C}$ signature, therefore only the purchase date of the seed is listed.

\begin{tabular}{|c|c|c|c|}
\hline Sample code & Sample description & Preparation date & $\begin{array}{l}\text { Project } \\
\text { collection }\end{array}$ \\
\hline $\begin{array}{l}\text { HART SEYNAEVE BATCH } 1 \text { UW } \\
\text { HART SEYNAEVE BATCH } 2.6 \text { UW } \\
\text { HART SEYNAEVE BATCH } 3 \text { UW } \\
\end{array}$ & Unwashed (UW) stack process flake white (lead white) & $\begin{array}{l}\text { Summer of } 2001 \text { or earlier } \\
\text { Summer of } 2003 \\
\text { Summer } 2004 \text { or } 2005 \\
\end{array}$ & $\begin{array}{l}\text { HART } \\
\text { HART } \\
\text { HART } \\
\end{array}$ \\
\hline $\begin{array}{l}\text { HART SEYNAEVE BATCH } 2 \text { WA } \\
\text { D-Schoonhoven }\end{array}$ & $\begin{array}{l}\text { Washed (WA) stack process flake white (lead white) } \\
\text { Commercial lead white from Schoonhoven factory }\end{array}$ & $\begin{array}{l}\text { Summer } 2003 \\
\text { Prior } 1989 \text { (factory closed) }\end{array}$ & $\begin{array}{l}\text { HART } \\
\text { MOLART }\end{array}$ \\
\hline$\overline{\text { K-Kremer }}$ & Lead white Kremer Pigmente $^{\text {a) }}$ (\# 46000) & $\begin{array}{l}\text { Prior } 1999 \text { (purchase } \\
\text { date) }\end{array}$ & MOLART \\
\hline $\begin{array}{l}\text { RM S2.18 SUWLOWE } \\
\text { (Oil paint reconstruction) }\end{array}$ & $\begin{array}{l}\mathrm{PbCO}_{3} \text { : HART SEYNAEVE BATCH 2.2 UW } \\
\text { Oil: water washed linseed oil (Electra seeds 2005) }\end{array}$ & $\begin{array}{l}\text { Summer of } 2003 \\
\text { Prior } 2005 \text { (supply date) }\end{array}$ & $\begin{array}{l}\text { HART } \\
\text { MOLART }\end{array}$ \\
\hline LZK (Oil paint reconstruction) & $\begin{array}{l}\mathrm{PbCO}_{3}: \text { Lead white Kremer Pigmente } \\
\text { Oil: }(\# 46000) \\
\text { ail } \text { (\#)ated linseed oil Z (Electra seeds) }\end{array}$ & $\begin{array}{l}\text { Prior } 1999 \text { (purchase date) } \\
\text { Prior } 2005 \text { (supply date) }\end{array}$ & $\begin{array}{l}\text { MOLART } \\
\text { HART }\end{array}$ \\
\hline TS1: SWA-14 (Oil paint reconstruction) & $\begin{array}{l}\mathrm{PbCO}_{3} \text { : HART SEYNAEVE BATCH } 2.6 \\
\text { Oil: untreated linseed oil (Electra seeds 2005) }\end{array}$ & $\begin{array}{l}\text { Summer } 2003 \\
\text { Prior } 2005 \text { (supply date) }\end{array}$ & $\begin{array}{l}\text { HART } \\
\text { HART }\end{array}$ \\
\hline TS1: SWA-AH2L (Oil paint reconstruction) & $\begin{array}{l}\mathrm{PbCO}_{3} \text { : HART SEYNAEVE BATCH } 2.6 \\
\text { Oil: linseed oil (Electra 2005) treated with litharge }\end{array}$ & $\begin{array}{l}\text { Summer } 2003 \\
\text { Prior } 2005 \text { (supply date) }\end{array}$ & $\begin{array}{l}\text { HART } \\
\text { HART }\end{array}$ \\
\hline $\begin{array}{l}\text { Umber trial paint mixed with Calcium carbonate } \\
\text { (in-house prepared mockup paint at SIK- } \\
\text { ISEA) }\end{array}$ & $\begin{array}{l}\mathrm{CaCO}_{3}: \text { Kremer champagne chalk } \\
\text { Oil: linseed oil Kremer Pigmente } \\
\text { a) } \\
\text { (\# 73504) }\end{array}$ & $\begin{array}{l}\text { N/A } \\
\text { Prior } 2005 \text { (purchase } \\
\text { date) }\end{array}$ & $\begin{array}{l}\text { N/A } \\
\text { N/A }\end{array}$ \\
\hline $\begin{array}{l}\text { Bleiweiss - Schoonhoven } \\
\text { (lead white paint, SIK-ISEA collection) }\end{array}$ & $\begin{array}{l}\mathrm{PbCO}_{3}: 20 \text { th cent. lead white from Schoonhoven } \\
\text { factory } \\
\text { Oil: linseed oil }{ }^{\text {b) }}\end{array}$ & $\begin{array}{l}\text { Unknown } \\
\text { Prior } 1981\end{array}$ & $\begin{array}{l}\text { N/A } \\
\text { N/A }\end{array}$ \\
\hline
\end{tabular}

${ }^{a}$ Kremer Pigmente GmbH \& Co, Aichstetten, Germany

${ }^{\mathrm{b}}$ Supplier and purchase date unknown. 


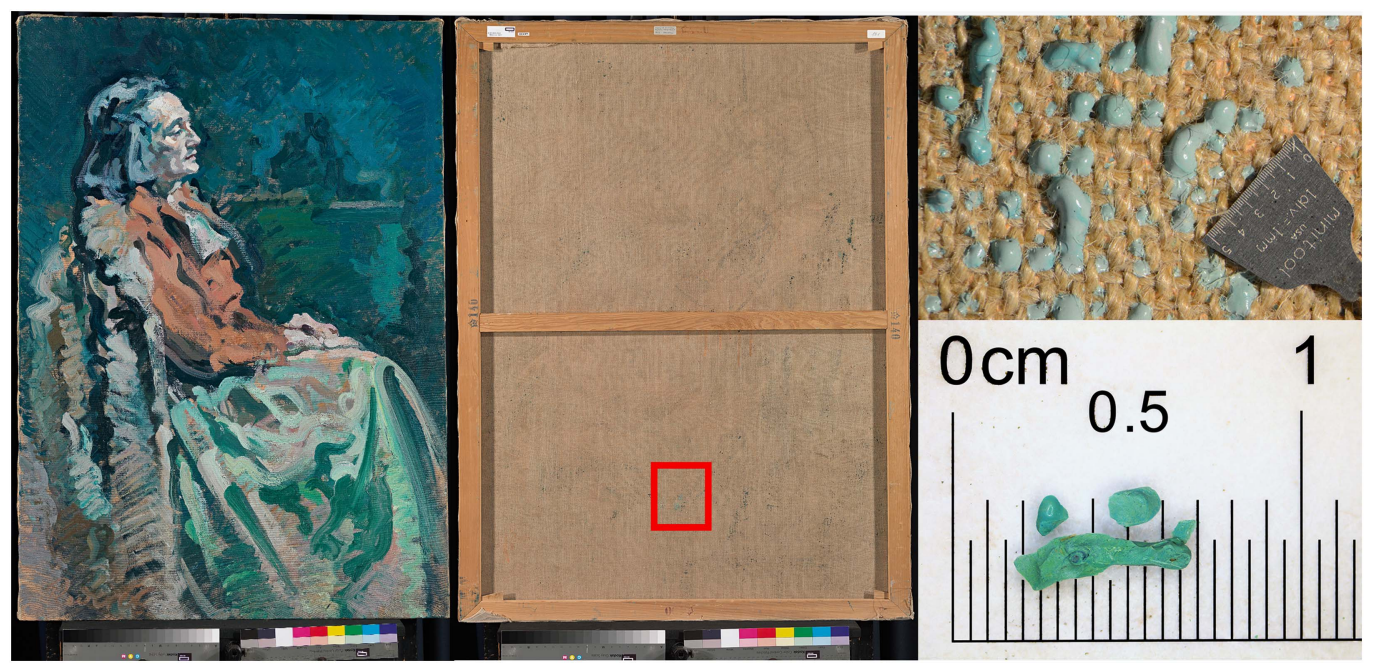

Figure 1 (Left) Bildnis Margrit mit roter Jacke und Konzertkleid, by Franz Rederer, 1962, oil on canvas, $140 \times$ $100 \mathrm{~cm}$, SIK-ISEA (archive Nr. 98 511). Middle: reverse side of the painting showing the sampled area in red. Photograph: SIK-ISEA (Philipp Hitz). (Right) green paint sampling on the reverse of the painting, where the scale used is $5 \mathrm{~mm}$. (Please see electronic version for colors.)

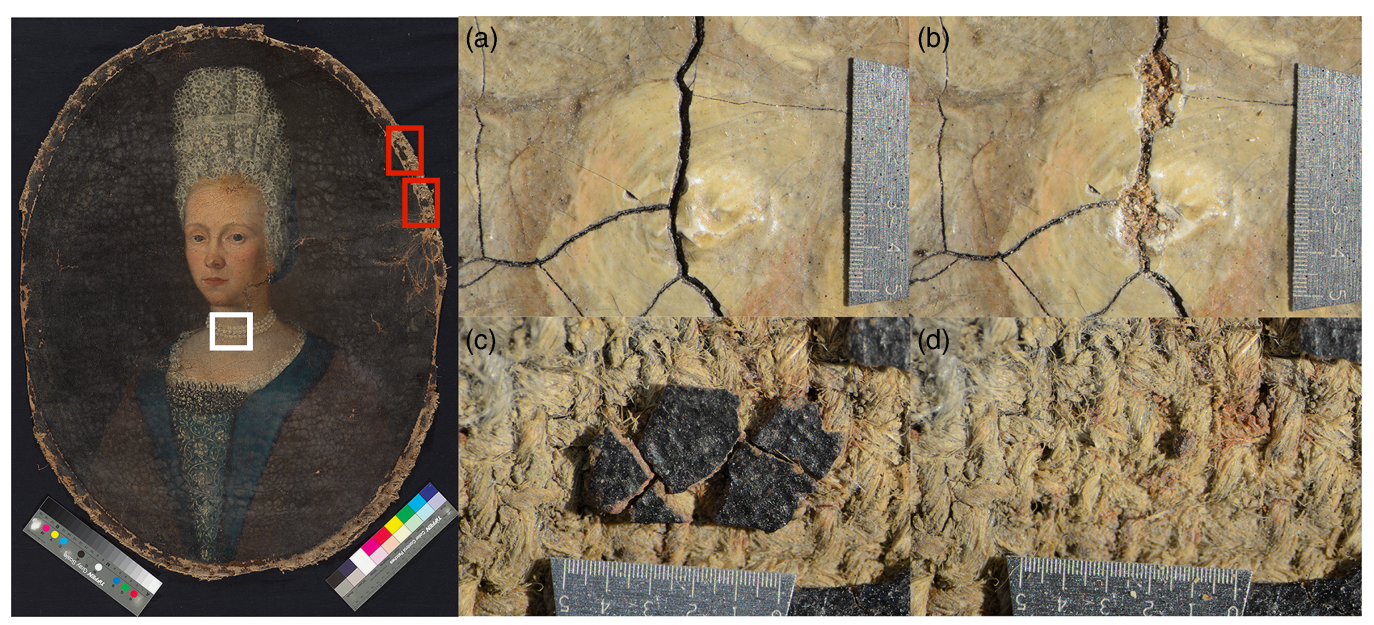

Figure 2 (Left) Untitled half-length portrait of a young woman wearing a lace bonnet, pearl necklace and furtrimmed cape, unsigned, ca. 17 th century, $57 \times 78 \mathrm{~cm}$, SIK-ISEA (Archive Nr. 171108 0002). Photograph: SIK-ISEA (Philipp Hitz). The lead white sampling location is marked by the white box, while the sampled brown paint and canvas are marked in red. (Right) The four details indicate the sampling location of lead white containing paint prior sampling (a) and after (b) and similarly for the brown paint prior sampling (c) and after (d). The scale used represents $5 \mathrm{~mm}$. (Please see electronic version for colors.)

using a $250 \mu \mathrm{m}$ steel micro chisel (Electron Microscopy Sciences, USA) for subsequent FTIR and ${ }^{14} \mathrm{C}$ analysis. FTIR spectra of the samples were collected in transmission mode on a Perkin Elmer System 2000 (Perkin Elmer, Massachusetts, USA) using a diamond cell. Acquisition parameters covered a spectral range from $4000-580 \mathrm{~cm}^{-1}$ with a resolution of $4 \mathrm{~cm}^{-1}$ and 16 scans. Complementary Raman analyses were acquired on a Renishaw in Via system with a 
diode type 785 laser source. The focus on the sample was achieved with a Leica DM microscope, using objectives of $50 \times$ and $100 \times$ magnification. The spectra were recorded using a laser power of $0.01-1 \mathrm{~mW}$ on sample and a measurement time between 30 and $200 \mathrm{~s}$. The collected data was interpreted using known reference databases (Burgio and Clark 2001; Scherrer et al. 2009).

\section{Carbonate Preparation for AMS ${ }^{14} \mathrm{C}$ Analysis}

In the context of artwork dating, sampling size is a crucial issue. In this study when working with reference material, sufficient material was available for graphitization of the carbonate (equivalent of $0.5-1 \mathrm{mg} \mathrm{C}$ ), while paint samples collected from oil paintings (see Case Studies) were too small and were therefore measured directly on the AMS as carbon dioxide released from the carbonate decomposition.

In order to yield $1 \mathrm{mg}$ of carbon required for graphitization, ca. $20 \mathrm{mg}$ of pure lead white pigment was necessary. Indeed, due to the heavy lead cation, lead white contains only $5 \%$ in weight of carbon when pure or even less when mixed with binder and/or other pigments as is often the case in real paint samples. Consequently, if the pigment to binder ratio is $1: 1$, twice as much paint is required to provide $1 \mathrm{mg} \mathrm{C}$. Therefore, a mass of ca. $40 \mathrm{mg}$ for paint reconstructions was used. The desired amount of material was weighed into $12 \mathrm{~mL}$ Exetainer ${ }^{\circledR}$ vials which were closed with septum screw caps (Labco, Lampeter, UK). The vials were flushed with He $(70 \mathrm{~mL} / \mathrm{min})$ for $10 \mathrm{~min}$ in the carbonate handling system (CHS) (Wacker et al. 2013a). Similarly to the processing of calcium carbonate (see Equation 5 and 6), lead carbonates samples were further dissolved by the addition of $0.5 \mathrm{~mL}$ analytical grade phosphoric acid $85 \%$ (Merck, Darmstadt, Germany) using a gastight syringe to avoid the contamination of the vial headspace with atmospheric $\mathrm{CO}_{2}$ (Hamilton Company, Nevada, USA) and left to react overnight at $75^{\circ} \mathrm{C}$.

$$
\begin{gathered}
3 \mathrm{CaCO}_{3}+2 \mathrm{H}_{3} \mathrm{PO}_{4} \rightarrow \mathrm{Ca}_{3}\left(\mathrm{PO}_{4}\right)_{2}+3 \mathrm{H}_{2} \mathrm{O}+3 \mathrm{CO}_{2} \\
3 \mathrm{PbCO}_{3}+2 \mathrm{H}_{3} \mathrm{PO}_{4} \rightarrow \mathrm{Pb}_{3}\left(\mathrm{PO}_{4}\right)_{2}+3 \mathrm{H}_{2} \mathrm{O}+3 \mathrm{CO}_{2}
\end{gathered}
$$

The coupling of the system to a commercially available auto-sampler (PAL-GC, CTC, Zwingen, Switzerland) allowed the direct transfer of the liberated $\mathrm{CO}_{2}$ by the carbonate decomposition to the automated graphitization equipment (AGE) (Wacker et al. 2010c). The amount of produced $\mathrm{CO}_{2}$ was manometrically quantified in a calibrated volume and further converted to $\mathrm{C}$.

In the case of the samples from the paintings, significantly smaller amounts of material were available, usually less than $1 \mathrm{mg}$ total, which includes the binding media, other pigments and lead white. In such small samples, the actual carbonate content is in the order of micrograms. The measurement was performed using the gas ion source, where the carbonate graphitization step was bypassed and the $\mathrm{CO}_{2}$ produced by the carbonate decomposition was directly fed into the MICADAS through the coupling of CHS to the gas ion source (GIS) interface (Fahrni et al. 2013; Wacker et al. 2013b). The samples were therefore weighed into $4 \mathrm{~mL}$ Exetainer ${ }^{\circledR}$ vials closed with septum, flushed with Helium and acidified with $0.5 \mathrm{~mL} \mathrm{H}_{3} \mathrm{P0}_{4}$.

\section{Oil Extraction for AMS ${ }^{14} \mathrm{C}$ Analysis}

Lead white oil paint, which is a mixture of lead hydroxycarbonate and an organic binder, contains carbon from two different sources, which can be independently dated. The possibility of radiocarbon dating the oil remaining in the sample after the carbonate decomposition was investigated following two strategies (see also under Results and Discussion): 
1. Organic phase extraction. The treatment of the carbonate bearing paint with phosphoric acid results in the formation of lead phosphate embedded within the binding media. This viscous solution, when given a few mL milli- ${ }^{\circledR}$ water (Merck Millipore, Darmstadt, Germany) forms a suspension. The oil molecules can be separated from the aqueous matrix based on a liquid-liquid extraction. For this purpose various solvents were tested as displayed in Table 1. The separation of the aqueous and organic phase was achieved by removing the aqueous phase with a syringe $(1 \mathrm{~mL}$, Codan medical $\mathrm{Ag}$, Baar, Switzerland $)$ and needle $(0.8 \times 80 \mathrm{~mm}$, B. Braun, Melsungen, Germany) and were further deposited into tarred cylindrical tin cups $(0.5 \mathrm{~mL}$, Elementar Analysensysteme $\mathrm{GmbH}$, Langenselbold, Germany). The organic solvent associated with the organic phase was then left to evaporate. The process was repeated several times, until 2-3 milligrams of oil were collected. The vessels and respective content weere then graphitized in the AGE system (Wacker et al. 2010c).

2. Modification of the protocol for carbonate decomposition. The use of hydrochloric acid for the removal of lead carbonates prior to dating of the organic binder was successfully demonstrated in a previous study (Hendriks et al. 2017). Hence, beginning with another paint sample the dissolution of the carbonates was pursued using hydrochloric acid (Merck Millipore, Darmstadt, Germany) instead of phosphoric acid. After the carbonate graphitization, the remaining material was given an additional $5 \mathrm{~mL} \mathrm{HCl} 1 \mathrm{M}$ and left to react for several hours at $80^{\circ} \mathrm{C}$ in the shaker. The remaining material was then washed with milli-Q ${ }^{\circledR}$ water, dried and graphitized.

\section{Radiocarbon Analysis}

In addition to the carbonate and oil analysis, the support material of the painting used as case study was also dated. Samples were first cleaned by Soxhlet extraction (Bruhn et al. 2001) followed by standard ABA procedure (Hajdas 2008). The cleaned canvas samples were then graphitized.

All ${ }^{14} \mathrm{C}$ AMS measurements were carried out on the Mini Carbon Dating System MICADAS at the Physics Department of ETH (Synal et al. 2007; Synal 2013), which allows for the analysis of both graphite and gaseous samples (Ruff et al. 2010; Wacker et al. 2010a).

Data evaluation was conducted using the data reduction program BATS (Wacker et al. 2010b). Radiocarbon ages were converted to calendar ages using the OxCal v.4.3.2 software (Ramsey 2008; Ramsey 2009) with either the IntCal13 atmospheric calibration curve or the post-bomb atmospheric NH1 calibration curve for samples dated post-1950 (Hua et al. 2013; Reimer et al. 2013). Data extending into 2000 and after were calibrated with the CALIBomb software (Stuiver and Reimer 1993; Stuiver et al. 2018) and the post-bomb calibration data set from Levin et al. (2013).

\section{RESULTS AND DISCUSSION}

The radiocarbon dating results for the lead white are divided into sub-sections. Firstly, the feasibility of lead white pigment dating by radiocarbon analysis is evaluated and discussed using pigment samples from the MOLART and HART project. Secondly, the results regarding the subsequent dating of the organic binder, after the carbonate ${ }^{14} \mathrm{C}$ dating on paints made with documented pigments and oil of known date, are presented. Finally, results from the two case studies (SIK-ISEA collection), including the spectroscopic characterization of the paint samples, are given followed by a discussion of the radiocarbon ages of the differently dated materials of these artworks. 


\section{Feasibility of Lead White ${ }^{14} \mathrm{C}$ Dating}

The lead white pigment samples from both the MOLART and HART project offer an ideal opportunity to compare the traditional stack process and modern manufacture. The respective ${ }^{14} \mathrm{C}$ signatures displayed in Table 3 demonstrate that stack produced lead white bears atmospheric ${ }^{14} \mathrm{C}$ levels while the commercially manufactured modern lead white samples studied are devoid of ${ }^{14} \mathrm{C}$.

In the particular case of the HART lead white produced following the stack process by Jeff Seynaeve, radiocarbon analysis can target the year of production. Indeed, upon calibration of the four radiocarbon ages of the samples he prepared (rows 1-4 in Table 3) two calendar ages are obtained due to the particular feature of the calibration curve, also known as the Bomb-peak. The first point occurs between 1954 and 1960 as the bomb peak rises and the second point occurs as it decreases. Both time windows are displayed in Table 3. Since the MOLART and HART projects were initiated in 1999 and 2002 respectively, the first time window can be dismissed as only the second time interval post-1960s is of relevance (highlighted in bold in the table). For each sample of the stack process lead white pigment, the second calibrated time interval correlates with the production year of the respective batch. Lead white prepared following modern processes cannot be dated "per se" but can be used as a marker for identifying lead white produced with alternative industrial methods to the traditional stack process. It is unfeasible to date lead white pigments prepared with radiocarbon-dead material. The chamber process patented by James Creed in the mid-18th century was the first to describe the use of fires, however when the wood was replaced by coal is unknown ${ }^{4}$. Gustav Dietel was the first to write a clear protocol describing the use of charcoal in 1838. In this work, for simplification, any radiocarbon dated lead white affording ages of more than a thousand years is designated as having been produced using ${ }^{14} \mathrm{C}$ devoid material, which arose with the beginning of industrialization, hence post-1800 was chosen as terminus post quem.

In oil paints, pigments and other additives are dispersed in a carbon rich organic binding medium. The influence of this additional carbon source was studied to determine if the presence of an oil binder would interfere with the measured carbonate ${ }^{14} \mathrm{C}$ ages. From the last four samples ETH-80056, ETH-80057, ETH-80058, and ETH-80059 in Table 3, it can be seen that the binder does not affect the dating of the carbonate from the lead pigment. The reaction specifically targets the carbonate and its decomposition to $\mathrm{CO}_{2}$. These results thus demonstrate the potential of applying this technique to real case studies. Additionally, in contrast to the dating of the organic binder (Hendriks et al. 2017), the method here proposed is unaffected by the presence of varnish layers or restoration materials. Indeed, newly added varnish layers as well as consolidants, which are all carbon-bearing materials, will not react with the acid used to decompose the lead white and therefore will not interfere with the ${ }^{14} \mathrm{C}$ dating of the carbonate. Moreover, the presence of organic pigments, carbon black or carbon containing impurities in the original paint (except $\mathrm{CaCO}_{3}$ ) will not disturb the result. This means that the method proposed has the advantage of not requiring any sample preparation in order to remove possible contaminations.

\section{Comparison of Different Preparations for the Two-Step Radiocarbon Dating of Lead White Oil Paint}

This work was undertaken to test the feasibility of successive radiocarbon dating of the lead white pigment and the organic binder from one paint sample. Two approaches to recover the oil fraction after the carbonate decomposition were tested and results were compared (Figure 4).

\footnotetext{
${ }^{4}$ The beginning of industrialization in the 18 th century had a direct impact on the consumption of wood as fuel. Indeed the growing demand for energy sources led to the shortage of wood and a significant price inflation of this source. The coal mining industry developed as a consequence. The substitution of coal over wood, however, did not occur uniformly and simultaneously across Europe.
} 
Table 3 Radiocarbon ages of the MOLART and HART lead white pigments and oil paint samples measured on ca. $1 \mathrm{mg}$ C. The exact amount of $\mathrm{C}$ was derived from the manometrical quantification of the carbon dioxide in a calibrated volume prior to the graphitization. The preparation date refers to the production year of the lead white pigment. All dates were calibrated in OxCal 4.3.2 using the post-bomb atmospheric NH1 calibration curve. The first time interval hitting the curve as it rises between 1956 and 1957 can be discarded as the MOLART and HART project were initiated after 1999 and 2002, respectively, only the second time window is of relevance (highlighted in bold).

\begin{tabular}{|c|c|c|c|c|c|c|}
\hline ETH-lab nr & Sample code & Preparation date & $\begin{array}{l}{ }^{14} \mathrm{C} \text { age } \pm 1 \sigma \\
(\mathrm{yr} \mathrm{BP})\end{array}$ & $\mathrm{F}^{14} \mathrm{C} \pm 1 \sigma$ & Production & Calibrated age $(95.4 \%)$ \\
\hline 80050.1 .1 & HART SEYNAEVE BATCH $1 \mathrm{UW}^{\text {a) }}$ & 2001 or earlier & $-749 \pm 21$ & $1.098 \pm 0.003$ & Stack process & $1956-1957 \&$ 1996-2001 \\
\hline 80051.1 .1 & HART SEYNAEVE BATCH $2.6 \mathrm{UW}^{\text {a) }}$ & 2003 & $-677 \pm 21$ & $1.088 \pm 0.003$ & Stack process & 1956-1957 \& 1999-2003 \\
\hline 80052.1 .1 & HART SEYNAEVE BATCH $3 \mathrm{UW}^{\text {a) }}$ & 2004 or 2005 & $-538 \pm 21$ & $1.069 \pm 0.003$ & Stack process & 1956-1957 \& 2002-2007 \\
\hline 80053.1 .1 & HART SEYNAEVE BATCH $2 \mathrm{WA}^{\text {a) }}$ & 2003 & $-642 \pm 21$ & $1.083 \pm 0.003$ & Stack process & 1956-1957 \& 2000-2004 \\
\hline 80054.1 .1 & D-Schoonhoven ${ }^{\text {a) }}$ & Prior 1989 & $27,285 \pm 78$ & $0.033 \pm 0.003$ & Industrial & Post-1800 \\
\hline 80055.1 .1 & K-Kremer ${ }^{\text {a) }}$ & Prior 1999 & $22,775 \pm 57$ & $0.059 \pm 0.003$ & Industrial & Post-1800 \\
\hline 80056.1 .1 & $\begin{array}{l}\text { RM S2.18 SUWLOWE }{ }^{\text {b) }} \\
\mathrm{PbCO}_{3}: \text { HART SEYNAEVE BATCH } 2.2 \text { UW }\end{array}$ & 2003 & $-614 \pm 21$ & $1.079 \pm 0.003$ & Stack process & 1956-1957 \& 2001-2004 \\
\hline 80057.1 .1 & $\begin{array}{l}\text { Kremer } \mathrm{LZK}^{\mathrm{b})} \\
\mathrm{PbCO}_{3}: \mathrm{K}-\mathrm{Kremer}\end{array}$ & Prior 1999 & $21,479 \pm 51$ & $0.069 \pm 0.000$ & Industrial & Post-1800 \\
\hline 80058.1 .1 & $\begin{array}{l}\text { TS1: SWA-14 b) } \\
\text { PbCO }_{3}: \text { HART SEYNAEVE BATCH } 2.6\end{array}$ & 2003 & $-705 \pm 21$ & $1.092 \pm 0.003$ & Stack process & $1956-1957 \&$ 1998-2002 \\
\hline 80059.1 .1 & $\begin{array}{l}\text { TS1: SWA-AH2L b) } \\
\text { PbCO }_{3}: \text { HART SEYNAEVE BATCH } 2.6\end{array}$ & 2003 & $-714 \pm 21$ & $1.093 \pm 0.003$ & Stack process & $\overline{1956-1957 \& \text { 1996-2002 }}$ \\
\hline
\end{tabular}

a)Pigment powder $\mathrm{UW}=$ unwashed, $\mathrm{WA}=$ washed.

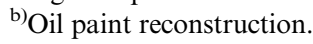




\section{Organic Phase Extraction after Carbonate Decomposition}

In the standard carbonate dating protocol (Wacker et al. 2013a), carbonates are decomposed by the reaction with phosphoric acid. Lead white reacts similarly to calcium carbonate and forms the corresponding lead phosphate salt. Upon addition of milli- $\mathrm{Q}^{\circledR}$ water to the remaining material after the carbonate decomposition a white suspension is formed. By adding an organic solvent, the hydrophobic oil fraction is extracted from the aqueous phase. Generally, for ${ }^{14} \mathrm{C}$ analysis the use of organic solvents should be avoided, as they potentially introduce additional $\mathrm{C}$ contamination. Highly volatile solvents were therefore preferred. All solvents tested in this study bear ages from 5000 to $50,000 \mathrm{yr}$ BP (see bottom plot of Figure 3). Hence in the case that the solvent did not fully evaporate, this would translate to an older age than expected. The measured ${ }^{14} \mathrm{C}$ concentration of the different oil extracts are displayed in Figure 3 . After the organic phase extraction and solvent evaporation, the radiocarbon dated extracts were expected to match the reference value of the binder from sample made with umber pigment $\left({ }^{14} \mathrm{C}\right.$ age $=$ $-544 \pm 20, \mathrm{~F}^{14} \mathrm{C}=1.070 \pm 0.003$ ) (Hendriks et al. 2016). Most extracts were, however, much older than anticipated, thus indicating residual solvent contamination. However, in the case of hexane, results demonstrate that this effect could be reduced to its minimum and the corresponding extract afforded matching results with the reference value.

Since hexane showed the most promising results, it was tested on several other paint reconstructions. The corresponding results are summarized in Table 4 and displayed in Figure 3. The Bleiweiss Schoonhoven paint was hereby effectively dated in two steps; the carbonate yielded more than 20,000 yr of age, indicating an non-traditional production while the oil was successfully dated to 1979-1981. Similar results were obtained for paint reconstructions from the MOLART and HART projects, where both the lead white and oil dating afforded corresponding results within the expected dates.

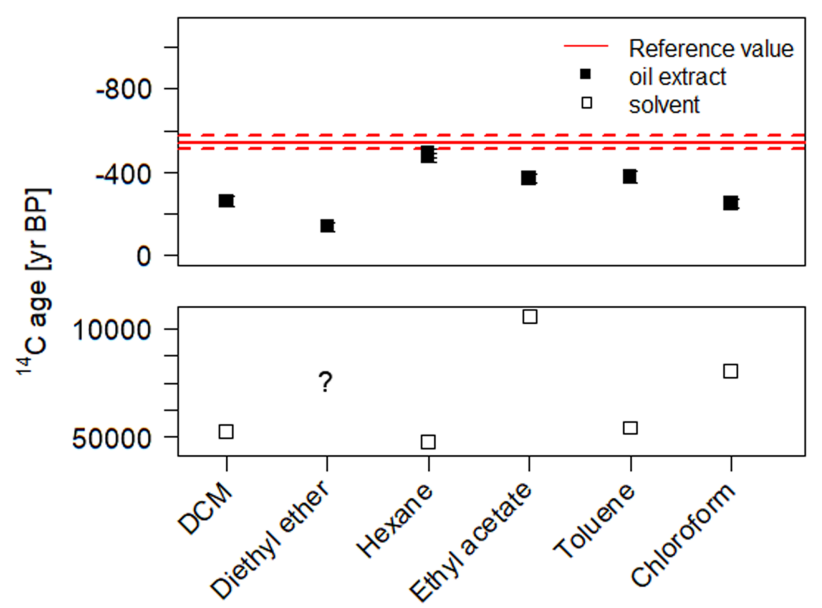

Figure 3 Radiocarbon ages of the extracted oil fraction from the SIKISEA umber and calcium carbonate sample after carbonate decomposition with $\mathrm{H}_{3} \mathrm{PO}_{4}$ and successive phase extraction using a variety of solvents. The reference value (in red) represents the measured ${ }^{14} \mathrm{C}$ concentration in the umber paint (reference material) and enables an assessment of the efficiency of the oil extraction procedure (filled squares) and potential contamination from solvent residues. For comparison, all the solvents were also dated (empty squares) only diethyl ether could not be dated as it is highly volatile. (Please see electronic version for colors.) 
Table 4 Radiocarbon ages of the SIK-ISEA umber and calcium carbonate, SIK-ISEA lead white paint, MOLART and HART lead white samples following the two step dating of the carbonates followed by the oil. The amount of carbon collected at the end of the graphitization process was derived from the manometrical quantification of carbon dioxide in a calibrated volume. The preparation date refers to production year of the lead white pigment. All dates were calibrated in OxCal 4.3.2 using the post-bomb atmospheric NH1 calibration curve. The first time interval, which hits the curve as it rises between 1956 and 1957, can be dismissed and only the second is of relevance (highlighted in bold).

\begin{tabular}{|c|c|c|c|c|c|c|c|c|}
\hline Sample code & Material age & $\begin{array}{l}\text { ETH- } \\
\text { Label }\end{array}$ & $\begin{array}{l}\text { Sample size } \\
(\mathrm{mg})\end{array}$ & $\begin{array}{l}\text { Targeted } \\
\text { material }\end{array}$ & $\begin{array}{c}\text { Measured C } \\
(\mu \mathrm{g})\end{array}$ & $\begin{array}{l}{ }^{14} \mathrm{C} \\
\text { age } \pm 1 \sigma \\
(\text { yr BP) }\end{array}$ & $\mathrm{F}^{14} \mathrm{C} \pm 1 \sigma$ & Calibrated age $(95.4 \%)$ \\
\hline \multirow{4}{*}{$\begin{array}{l}\text { Umber trial paint } \\
\text { mixed with } \\
\mathrm{CaCO}_{3}\end{array}$} & $\mathrm{CaCO}_{3}:$ & 83533.7 .1 & 23.1 & Carbonate $^{\text {a) }}$ & 485 & $20,725 \pm 108$ & $0.076 \pm 0.001$ & N/A \\
\hline & $\begin{array}{l}\text { Unknown } \\
(>20,000 \mathrm{yr})\end{array}$ & 83533.9 .1 & 22.6 & Carbonate $\left.^{b}\right)$ & 501 & $15,908 \pm 65$ & $0.138 \pm 0.003$ & N/A \\
\hline & Oil: prior 2005 & 83533.8 .1 & 23.1 & Oil $^{\text {a) }}$ & 789 & $-472 \pm 16$ & $1.067 \pm 0.002$ & $1956-1957 \& 2005$ \\
\hline & (purchase date) & 83533.10 .1 & 22.6 & $\mathrm{Oil}^{\mathrm{b})}$ & 965 & $-522 \pm 16$ & $1.067 \pm 0.002$ & $1956-1957 \&$ 2004-2008 \\
\hline \multirow{4}{*}{$\begin{array}{l}\text { Bleiweiss - } \\
\text { Schoonhoven }\end{array}$} & $\mathrm{PbCO}_{3}$ : industrial & 82895.1 .1 & 37.0 & Carbonate $^{\text {a) }}$ & 862 & $20,804 \pm 46$ & $0.075 \pm 0.000$ & Post-1800 \\
\hline & & 82895.3 .1 & 30.0 & Carbonate $^{\mathrm{b})}$ & 979 & $20,944 \pm 58$ & $0.074 \pm 0.001$ & Post-1800 \\
\hline & Oil: 1981 & 83552.2 .1 & 37.0 & Oil $^{\text {a) }}$ & 280 & $-1992 \pm 24$ & $1.282 \pm 0.003$ & $1959-1962 \&$ 1979-1981 \\
\hline & & 83552.1 .1 & 30.0 & $\mathrm{Oil}^{\mathrm{b})}$ & 993 & $-2059 \pm 22$ & $1.292 \pm 0.003$ & $1961-1962 \&$ 1979-1980 \\
\hline \multirow{7}{*}{$\begin{array}{l}\text { RM S2.18 } \\
\text { SUWLOWE }\end{array}$} & $\mathrm{PbCO}_{3}: 2003$ & 80056.6 .1 & 40.8 & Carbonate $^{\text {a) }}$ & 998 & $-616 \pm 15$ & $1.080 \pm 0.002$ & 1956-1957 \& 2001-2004 \\
\hline & & $80056.2 .1^{*}$ & 17.2 & Carbonate $^{\text {a) }}$ & 598 & $-777 \pm 56$ & $1.101 \pm 0.008$ & 1956-1957 \& 1995-2002 \\
\hline & & 80056.7 .1 & 42.8 & Carbonate $^{\mathrm{b})}$ & 447 & $-549 \pm 22$ & $1.071 \pm 0.003$ & 1956-1957 \& 2002-2006 \\
\hline & & $80056.3 .1^{*}$ & 11.3 & Carbonate $^{\mathrm{b})}$ & 37 & $-773 \pm 61$ & $1.101 \pm 0.010$ & $1956-1957 \&$ 1995-2002 \\
\hline & Oil: prior 2005 & 80680.3 .1 & 40.8 & Oil $^{\text {a) }}$ & 513 & $-651 \pm 21$ & $1.084 \pm 0.003$ & 1956-1957 \& 2000-2003 \\
\hline & (seed purchase & 80680.4 .1 & 42.8 & Oil $^{\text {b) }}$ & 983 & $-563 \pm 16$ & $1.073 \pm 0.003$ & 1956-1957 \& 2002-2005 \\
\hline & date) & 80056.5 .1 & 11.3 & Oil b) & 584 & $-673 \pm 23$ & $1.087 \pm 0.003$ & 1956-1957 \& 1999-2003 \\
\hline \multirow{5}{*}{$\begin{array}{l}\text { TS1: } \\
\text { SWA-14 }\end{array}$} & $\mathrm{PbCO}_{3}: 2003$ & 80058.6 .1 & 39.5 & Carbonate $^{\text {a) }}$ & 846 & $-735 \pm 16$ & $1.096 \pm 0.003$ & $1956-1957 \&$ 1998-2001 \\
\hline & & 80058.7 .1 & 43.7 & Carbonate $^{\mathrm{b})}$ & 208 & $-613 \pm 28$ & $1.079 \pm 0.003$ & $1956-1957$ \& 2001-2004 \\
\hline & & $80058.3 .1^{*}$ & 11.3 & Carbonate $^{\mathrm{b})}$ & 19 & $-885 \pm 95$ & $1.116 \pm 0.014$ & $1957-1958 \&$ 1991-2001 \\
\hline & Oil: prior 2005 & 80682.4 .1 & 39.5 & Oil $^{\text {a) }}$ & 902 & $-521 \pm 16$ & $1.067 \pm 0.002$ & $1956-1957 \&$ 2004-2007 \\
\hline & $\begin{array}{l}\text { (seed purchase } \\
\text { date) }\end{array}$ & 80682.6 .1 & 43.7 & Oil $^{\text {b) }}$ & 286 & $-596 \pm 26$ & $1.077 \pm 0.003$ & 1956-1957 \& 2001-2005 \\
\hline
\end{tabular}

${ }^{*}$ Directly measured as $\mathrm{CO}_{2}$ using the GIS interface.

Chemical treatment: ${ }^{\text {a) }}$ Carbonate decomposition with $\mathrm{H}_{3} \mathrm{PO}_{4}$ followed by hexane extraction of the oil fraction, ${ }^{\text {b) }} \mathrm{HCl} 1 \mathrm{M}$. 
This extraction procedure has however its downfalls; after the hexane extraction the remaining hydrophobic paint material aggregates and sticks to the vial walls. Thus, this laborious and time-consuming transfer of material to the tin cups results in low yields.

\section{Alternative Carbonate Decomposition by Hydrochloric Acid}

Phosphoric acid is the standard acid for the preparation of carbonates for ${ }^{14} \mathrm{C}$ analysis. Its substitution with hydrochloric acid was pursued based on knowledge gained in a prior study (Hendriks et al. 2017), where lead carbonates were successfully removed prior to ${ }^{14} \mathrm{C}$ dating of the organic binder by using hydrochloric acid. This second approach based on the acid substitution has several advantages, namely no additional organic solvent is used and it is less labor intensive as the sample only requires drying. Comparable carbon dioxide yields were achieved using either phosphoric acid or $1 \mathrm{M} / 0.5 \mathrm{M} \mathrm{HCl}$, while only half of the amount of carbon was gained using $0.2 \mathrm{M} \mathrm{HCl}$. A blank assessment was performed using different $\mathrm{HCl}$ molarities $(1 \mathrm{M}$, $0.5 \mathrm{M}$, and $0.2 \mathrm{M}$ ) and no significant difference in the blank level was observed. Thus, the use of $1 \mathrm{M} \mathrm{HCl}$ was determined to be the most efficient procedure.

The sequential dating of the carbonate followed by the organic binder was also tested using $1 \mathrm{M}$ $\mathrm{HCl}$ on several paint reconstructions (see Table 4 and Figure 4). The $\mathrm{F}^{14} \mathrm{C}$ of the oil binder in the paint pigmented with umber and calcium carbonate after $1 \mathrm{M} \mathrm{HCl}$ treatment, matches the reference date of the oil. The oil binder of the lead white paint prepared in 1981 could be dated to $1979-1980$. Similarly to the hexane extraction procedure, both carbonate and oil fraction

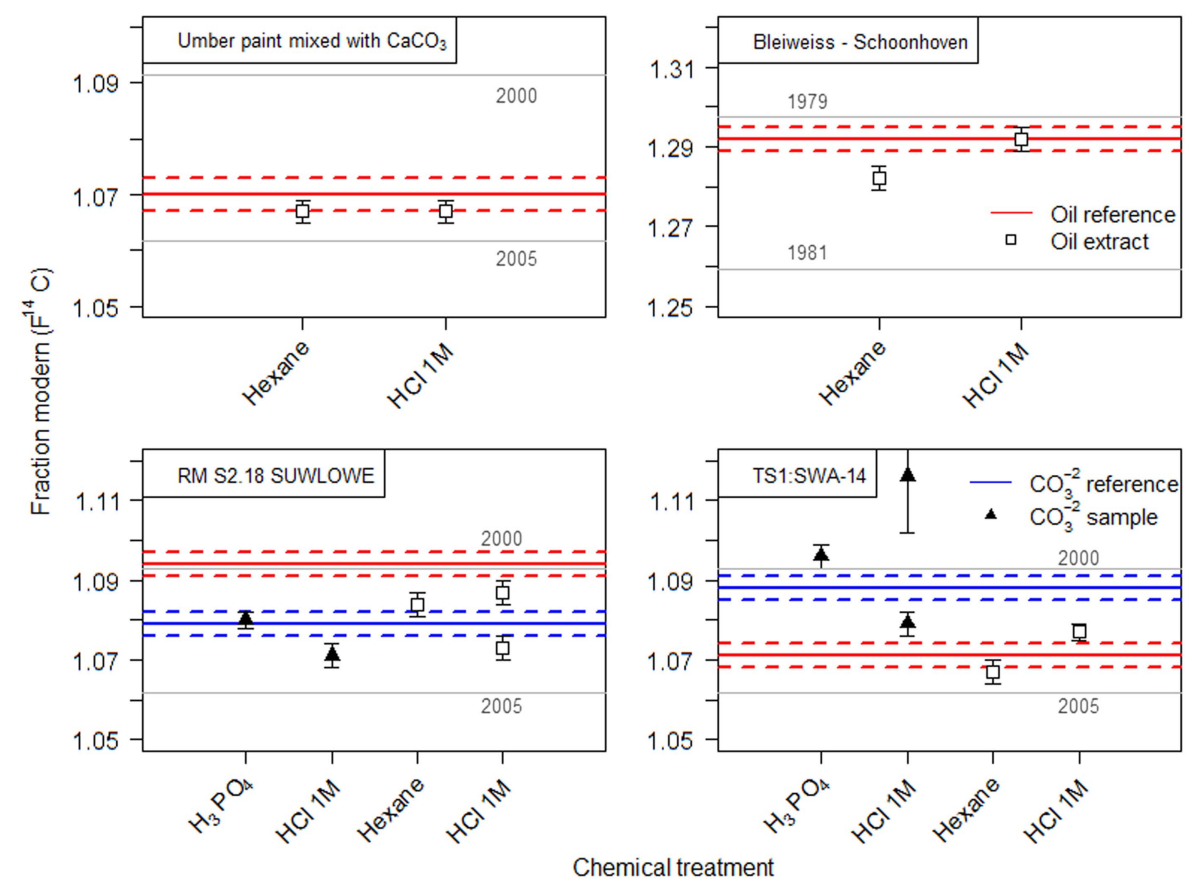

Figure 4 Results for the two-step dating of lead white oil paint measured on $1 \mathrm{mg}$ of C. Solid lines depict the age of the reference material, dashed lines the respective uncertainty. Dating of the recovered oil fraction (square symbols) by hexane extraction or by using $1 \mathrm{M} \mathrm{HCl}$ is compared in the top figures. The effect of substituting phosphoric acid with $1 \mathrm{M} \mathrm{HCl}$ for carbonate decomposition and subsequent dating of the oil fraction within the same sample is compared in the lower figures. (Please see electronic version for colors.) 
from two MOLART and HART samples (codes RM S2.18 SUWLOWE and TS1: SWA-14), could be dated following the $1 \mathrm{M} \mathrm{HCl}$ treatment. However, it should be noted that sample size turned out to be a crucial factor. Large aggregates of sample material tended to hinder the carbonate decomposition reaction, as the diffusion rate of the acid within the core was limited, resulting in an incomplete reaction and biased $\mathrm{F}^{14} \mathrm{C}$ value of the oil fraction. Nevertheless, in the case of smaller samples the sequential radiocarbon age of the oil fraction agrees with the reference value and hence validates the method. Thus it is important to monitor and ensure complete carbonate decomposition by FTIR analysis.

In comparison to the standard protocol involving $\mathrm{H}_{3} \mathrm{P0}_{4}$, the use of $1 \mathrm{M} \mathrm{HCl}$ results in similar carbon dioxide yields after the carbonate decomposition. For the $1 \mathrm{M} \mathrm{HCl}$ process, much higher yields are observed for the recovered material, an advantage for subsequent oil dating.

\section{CASE STUDIES}

\section{Spectroscopic Analysis of the Paintings Investigated}

The dating of lead carbonate requires the characterization of paint mixtures in order to identify and select lead carbonate containing paint. The results of the paint characterization combining XRF, FTIR and Raman analysis are displayed in Table 5. The identification of lead as main element in the unsigned baroque painting is not surprising, as up until the 19th century lead white was widely used in oil paint. Additionally, among the elements identified by XRF, varying concentrations of calcium were also found. This finding has important implications for the radiocarbon dating of the lead carbonate, as the presence of calcium carbonate will introduce a source of contamination. In sample P03 pearl, traces of Ca were observed in the XRF but no calcium compound was discernible in the FTIR spectra. On the contrary in the paint sample P04 brown, Ca was identified as major component, which was confirmed by FTIR as being dolomite. For this reason and to avoid contamination sources, only the lead white from P03 pearl was radiocarbon dated and the brown paint was avoided. However, no other C-bearing pigments were found in the P04 brown paint sample and therefore the brown paint was deemed suitable for further ${ }^{14} \mathrm{C}$ analysis of the organic binder.

In the case of Margrit's painting, zinc was found as the main element followed by lead and titanium, hence indicating that the artist probably used a commercially blended white containing lead white because of its drying properties. Although lead white was not found to be the main paint component, its dating was nonetheless pursued.

\section{Radiocarbon Results for the Case Studies}

Radiocarbon data of the selected samples from the female portrait are summarized in Table 6, while ${ }^{14} \mathrm{C}$ results for Rederer's painting are presented in Table 8 . The quantities of paint sampled for this study range from approximatively $5 \mathrm{mg}$ to hundreds of micrograms of total material. This includes the binding media, other pigments and lead white. The resulting $\mathrm{C}$ content was far below the desired $1 \mathrm{mg}$ for graphitization and consequently the ${ }^{14} \mathrm{C}$ analyses were measured as $\mathrm{CO}_{2}$ directly, resulting in higher measurement uncertainty. From the data in Table 6 the mean values were determined for samples P03 pearl and P04 brown taken from the female portrait. All the ${ }^{14} \mathrm{C}$ ages were calibrated to the corresponding calendar ages in Table 7.

\section{Half-Length Female Portrait (ca. 17th Cent.)}

In the study of the half-length female portrait, we sampled not only lead white paint but also canvas threads and the brown paint for radiocarbon dating. Upon calibration the textile's ${ }^{14} \mathrm{C}$ 
Table 5 Combined results from the multi-technique approach to determine the paint composition of selected samples from the paintings under study: the half-length female portrait by an unknown artist and Bildnis Margrit mit roter Jacke und Konzertkleid by Franz Rederer. The $\mathrm{XRF}$ data is reported in bold for major elements, while traces are indicated in brackets.

\begin{tabular}{|c|c|c|c|c|}
\hline Painting & Sample description & Method & Laboratory data & Interpretation \\
\hline \multirow{10}{*}{$\begin{array}{l}\text { Half-length female portrait } \\
\text { (ca. 17th century) }\end{array}$} & P03 pearl & XRF & $\mathbf{P b}, \mathrm{Fe},(\mathrm{K}, \mathrm{Ca}, \mathrm{Hg})$ & $\mathrm{PbCO}_{3}$, ochre, $\mathrm{HgS}$ \\
\hline & $\rightarrow 283 \mathrm{~mm}$ & $F T I R$ & $2925,2854,1738,1169,1094$ & Oxidized oil \\
\hline & $\uparrow 344 \mathrm{~mm}$ & $\left(\mathrm{~cm}^{-1}\right)$ & $3537,1407,1045,839,682$ & Lead white \\
\hline & & & 1528 & Lead carboxylates \\
\hline & $\begin{array}{l}\text { P04 brown } \\
\rightarrow 560 \mathrm{~mm}\end{array}$ & $\mathrm{XRF}$ & $\mathbf{P b}, \mathbf{F e}, \mathbf{C a}, \mathrm{Mn}, \mathrm{Ti}, \mathrm{K},(\mathrm{Cu}, \mathrm{Zn}, \mathrm{Hg}, \mathrm{P})$ & $\begin{array}{c}\mathrm{PbCO}_{3} \text {, ochre, umber, } \\
\text { earth pigment, } \mathrm{HgS}\end{array}$ \\
\hline & $\uparrow 525 \mathrm{~mm}$ & FTIR & $3695,3618,1034,1009,940,912$ & Kaolinite \\
\hline & & $\left(\mathrm{cm}^{-1}\right)$ & $2919,2849,1709,1514,1187$ & Oxidized oil \\
\hline & & & $2510,1791,1420,1094,875,719$ & Dolomite \\
\hline & & & 680 & Lead white \\
\hline & & & $2013,1459,961,875,700,603$ & Bone black \\
\hline \multirow{6}{*}{$\begin{array}{l}\text { "Margrit" } \\
\text { (1962) by Franz Rederer. } \\
\text { (Hendriks et al. 2018) }\end{array}$} & P05 green & $X R F$ & $\mathrm{Zn}, \mathrm{Pb}, \mathrm{Ti},(\mathrm{Cr}, \mathrm{Ca}, \mathrm{Mn}, \mathrm{Fe}, \mathrm{Co}, \mathrm{Cu})$ & $\mathrm{ZnO}, \mathrm{TiO}_{2}, \mathrm{PbCO}_{3}$ \\
\hline & (reverse) & FTIR & $2925,2853,1741,1458,1162$ & Linseed oil \\
\hline & $\rightarrow 486 \mathrm{~mm}$ & $\left(\mathrm{~cm}^{-1}\right)$ & $3542,1405,1043,839,681$ & Lead white \\
\hline & $\uparrow 252 \mathrm{~mm}$ & Raman & $141 \mathrm{~s}$ & $\mathrm{TiO}_{2}$-anatase \\
\hline & & $\left(\mathrm{cm}^{-1}\right)$ & $587,547 \mathrm{~s}, 374$ & Ultramarine \\
\hline & & & $1542 \mathrm{~s}, 1341,1218,775,741,686$ & PG7 (traces) \\
\hline
\end{tabular}


Table 6 Selected samples from the female half-length portrait for ${ }^{14} \mathrm{C}$ analysis including sample description, initial weight, carbon content, and respective radiocarbon age.

\begin{tabular}{lllccc}
\hline ETH label & Sample description & Material & Mass $(\mathrm{mg})$ & $\mathrm{C}$ content $(\mu \mathrm{g})$ & ${ }^{14} \mathrm{C}$ age $\pm 1 \sigma(\mathrm{yr}$ BP $)$ \\
\hline 82986.2 .1 & P03 pearl & Carbonate & 1.57 & 27 & $316 \pm 65$ \\
82986.3 .1 & P03 pearl & Carbonate & 0.55 & 8 & $388 \pm 91$ \\
82999.1 .1 & P04 brown & Oil & & 198 & $271 \pm 58$ \\
82999.1 .2 & P04 brown & Oil & \multirow{6}{*}{6.45} & 150 & $350 \pm 60$ \\
82999.1 .3 & P04 brown & Oil & & 78 & $345 \pm 56$ \\
82988.1 .1 & Canvas & Textile & 8.7 & 991 & $164 \pm 22$ \\
\hline
\end{tabular}

Table 7 Painting, sample number, description, measured ${ }^{14} \mathrm{C}$ ages and respective calibrated age range using IntCal13 (Reimer et al. 2013).

\begin{tabular}{llllll}
\hline Painting & $\begin{array}{l}\text { ETH } \\
\text { label }\end{array}$ & $\begin{array}{l}\text { Sample } \\
\text { description }\end{array}$ & Material & $\begin{array}{l}{ }^{14} \mathrm{C} \text { age } \pm 1 \sigma \\
(\mathrm{yr} \text { BP })\end{array}$ & $\begin{array}{l}\text { Calibrated age range } \\
(95.4 \%)\end{array}$ \\
\hline Female half- & 82986 & P03 pearl & Carbonate & $341 \pm 53$ & $1451-1646$ \\
length portrait & 82999 & P04 brown & Oil & $322 \pm 34$ & $1478-1646$ \\
(ca. 17th cent.) & 82988.1 .1 & Canvas & Textile & $164 \pm 22$ & $1665-1697 \& 1725-1785 \&$ \\
& & & & & $1793-1877 \& 1916-1950$ \\
\hline
\end{tabular}

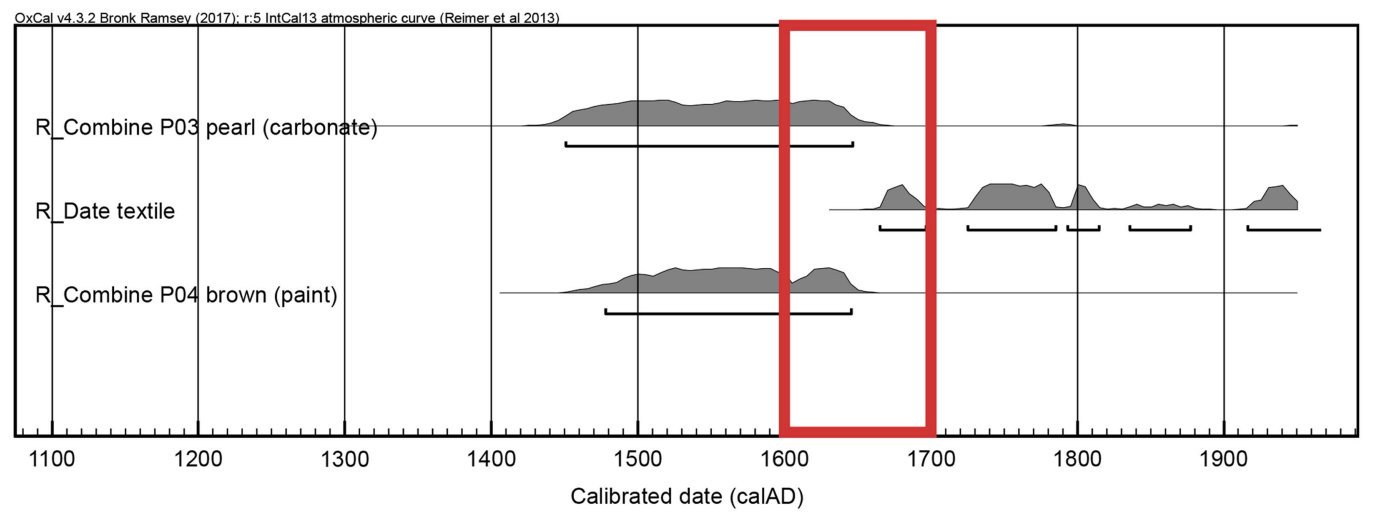

Figure 5 Calibrated ages for the set of samples collected on the female portrait. The red box highlights the time range where the calibrated ages of all three materials (carbonate, canvas, and binder) are in agreement. (Please see electronic version for colors.)

age hits the curve at several points, yielding multiple time intervals ranging from the mid-17th to the mid-20th century. These results are in accordance with the art historical dating of the artwork, namely the female portrait was painted during the turn of the late 17 th and early 18 th century. However, it is also worth keeping in mind that dating of an object based on a fashion style gives only the earliest possible date, it could well be a later copy, which cannot be ruled out by the wide range of calibrated radiocarbon age. Thus, the ${ }^{14} \mathrm{C}$ age of the canvas does not provide any decisive argument regarding the age of the painting. Therefore the dating of other materials than the support, such as the organic binder and the lead white pigment, become 
important. The mean value of the two carbonate measurements is $341 \pm 53 \mathrm{BP}$, which after calibration yields a time range between the mid-15th to the mid-17th century and a matching result is obtained on the organic binder from the brown paint. One can conclude that the additional dating of the lead white and oil helps to narrow down the time window given by the ${ }^{14} \mathrm{C}$ age of the canvas, hereby excluding a possible later creation during the 18 th, 19 th or 20 th century (Figure 5). These results also highlight offsets between the age of materials, which can be due to possible storage times, for instance the pigments and oil may have been stored for the time of one generation in comparison to the canvas. A direct correlation between the age of the pigment and the age of the oil must not always be the case, as either one could be much older than the other. It is known that painters kept materials around in their studios for decades, which were then passed on to other artists after their death.

What has not been investigated and is worth mentioning is the potential impact of remineralization of the lead carboxylate in heavily saponified lead white oil paints. This form of alteration of lead pigmented oil paint layers has been observed in various paintings spanning the 15 th to 20 th century (Keune 2005). However, much of the research up to now has been descriptive in nature of the phenomenon and the causes of the remineralisation are still presently unexplained (Boon et al. 2002). Since the mechanism are still uncertain, it is not clear if the remineralization of lead carboxylates to lead carbonates will interfere with the ${ }^{14} \mathrm{C}$ dating of the carbonate. In the female portrait studied, the distinct peak at $1528 \mathrm{~cm}^{-1}$ in the FTIR spectra can be attributed to the COO-group of metal carboxylates, commonly referred to as soaps. This raises the question of possible remineralisation back to lead carbonate or lead hydroxycarbonate, which may introduce some probably very minor but at the moment unknown error in the dating of the pigment. In the current case we surmise that the age of the carbonate produced following the traditional stack process should be in agreement with the one of the binder as demonstrated in Figure 5, and such remineralization process should bear little impact on the measured ${ }^{14} \mathrm{C}$ age of the global lead carbonate fraction.

\section{Bildnis Margrit mit Roter Jacke und Konzertkleid (1962)}

In the case of Rederer's painting, the negative radiocarbon ages indicate that the dated samples are post-1950, hence the respective ${ }^{14} \mathrm{C}$ ages and uncertainty are additionally given as fraction modern $\mathrm{F}^{14} \mathrm{C}$ (see Table 8).

The characteristic signature of fossil fuels was detected in the carbonate of P05 green, thus indicating that the lead white pigment was made following a modern industrial process. This

Table 8 Radiocarbon results given as ${ }^{14} \mathrm{C}$ ages and fraction modern for the samples of Rederer's painting.

\begin{tabular}{|c|c|c|c|c|c|c|}
\hline $\begin{array}{l}\text { ETH } \\
\text { label }\end{array}$ & $\begin{array}{l}\text { Sample } \\
\text { description }\end{array}$ & Material & $\begin{array}{l}\text { Mass } \\
(\mathrm{mg})\end{array}$ & $\begin{array}{l}\text { C content } \\
(\mu \mathrm{g})\end{array}$ & $\begin{array}{l}{ }^{14} \mathrm{C} \text { age } \pm 1 \sigma \\
(\mathrm{yr} \mathrm{BP})\end{array}$ & $\mathrm{F}^{14} \mathrm{C} \pm 1 \sigma$ \\
\hline 57442.2 .1 & Canvas & Textile & 26.0 & 997 & $-888 \pm 25$ & $1.117 \pm 0.004^{a)}$ \\
\hline 69023.1 .1 & P04 white & Oil & 2.6 & 284 & $-161 \pm 30$ & $1.020 \pm 0.004^{\text {a) }}$ \\
\hline 69024.1 .1 & P05 green & Oil & 8.5 & 398 & $-183 \pm 30$ & $1.023 \pm 0.004^{\mathrm{a})}$ \\
\hline 69024.4 .1 & P05 green & Carbonate & 7.8 & 93 & $25,724 \pm 223$ & $0.041 \pm 0.005$ \\
\hline 69024.6 .1 & P05 green & Carbonate & & 246 & $23,841 \pm 166$ & $0.051 \pm 0.001$ \\
\hline 69024.7 .1 & P05 green & Oil b) $^{\text {b) }}$ & 5.0 & 425 & $-597 \pm 22$ & $1.077 \pm 0.003$ \\
\hline
\end{tabular}

${ }^{a)}$ Data already published in Hendriks et al. (2018).

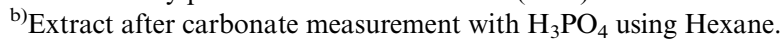


result is compatible with the hypothesis that the artist, Franz Rederer, who lived in the 20th century, in his paint used lead white that came from a commercial industrial source. Indeed, the production of lead white following modern industrial methods began in the 19th century and its identification in Rederer's painting dated to 1962 is fully appropriate.

It is interesting to highlight the sample size, indeed as already mentioned pure lead white pigment contains only 5\% C. In paint samples this $\mathrm{C}$ content becomes even lower as the lead white is mixed with an organic binder and is applied to the painting. Upon mixing with other pigments, in this case with ultramarine and PG7, this C contribution from the lead white can go down to $1 \%$. Nevertheless, both spectroscopic analysis and AMS measurement enabled its identification.

As already mentioned in a prior study, the Rederer's painting is an ideal case study in the sense, that it has a legitimate provenance, has undergone no restoration and is not varnished. Thus, the additional extraction of the binder and subsequent dating after carbonate measurement could proceed without additional cleaning steps. Phosphoric acid was used to decompose the lead white and liberate carbon dioxide, then the oil was extracted from the remaining viscous material by an organic phase separation involving hexane. The results are straightforward; the oil dates to $-597 \pm 22 \mathrm{yr}$ BP, which upon calibration using the post-bomb atmospheric NH1 curve (Hua et al. 2013) affords two time windows, namely 1957 and 2001-2005. The later can be excluded as it postdates the artist's death in 1965. The radiocarbon dating of the remaining organic binder affords a growing season year for the oil seeds in 1957, which is in line with the signed date of 1962 . Hence from one unique sample weighing $15 \mathrm{mg}$, followed by a two-step preparation, both the lead white and organic binder were successfully dated and results correlate with the time frame of the artist's activity.

\section{CONCLUSION}

This work demonstrates the potential of using radiocarbon analysis for dating other materials than an artwork's support. The procedure presented for the dating of the lead white pigment has the advantage of being material specific, since only the inorganic carbonate will be released as carbon dioxide independent of any other carbon containing material (organic pigment, varnish, ...). A distinction between manufacturing processes with different $\mathrm{CO}_{2}$ sources can be achieved based on the different ${ }^{14} \mathrm{C}$ signature. The results show that the radiocarbon ages for lead white pigments produced following the traditional stack process match their production years. Lead white pigments from other industrial methods cannot provide the age as such but can be used as a marker to indicate manufacturing processes which do not follow the traditional stack method. Lead carbonate can therefore be used as a proxy for the time of creation of the painting (by providing a creation date no earlier than the time of the pigment manufacture where the stack method was used), and for identifying later interventions or detecting pigment anachronisms.

Furthermore, this work is not only a feasibility study, as the method developed for dating lead carbonate was successfully applied to the analysis of two real case oil paintings. The measured ${ }^{14} \mathrm{C}$ ages of the lead white pigments are chronologically compatible with the period to which the paintings were attributed.

The two-step method of sample preparation introduced here allows the sequential dating of the carbonate, followed by the dating of the organic binder. This ability to derive two-fold information from a single sample is important since it reduces the sampling required and hereby increases the value of the ${ }^{14} \mathrm{C}$ analysis. It is important to note that while the lead white pigment 
dating is material specific, for analysis of the organic component (the binder), no additional materials, such as varnish, retouching or consolidants can be present in the sample since they will influence the ${ }^{14} \mathrm{C}$ results.

To conclude, radiocarbon dating has great potential for application to studies of works of art, however one must always bear in mind that it is the time of formation of carbon-bearing material, which is radiocarbon dated and not the time of painting, thus an offset between radiocarbon age and artwork creation must always to be considered.

\section{ACKNOWLEDGMENTS}

This study was funded by an ETH-grant (ETH-21 15-1). The authors gratefully acknowledge the contribution of both the MOLART and HART projects which allowed preliminary feasibility studies. We wish to thank the Swiss Institute for Art Research (SIK-ISEA) for their collaboration in the study and for the access given to their painting collection. In particular we wish to acknowledge Jens Stenger for the introduction to handling of the XRF instrument, as well as Lukas Wacker and Negar Haghipour for their help running the CHSAMS measurement. Also to be thanked are the reviewers who helped to improve this manuscript.

\section{SUPPLEMENTARY MATERIAL}

To view supplementary material for this article, please visit https://doi.org/10.1017/RDC. 2018.101

\section{REFERENCES}

Boon JJ, van der Weerd J, Keune K, Noble P, Wadum J. 2002. Mechanical and chemical changes in Old Master paintings: dissolution, metal soap formation and remineralization processes in lead pigmented ground/ intermediate paint layers of 17 th century paintings. In: Vontobel R, editor. 13th Triennial Meeting of the ICOM Committee for Conservation in Rio De Janeiro Preprints. London: James \& James. p. 401.

Bruhn F, Duhr A, Grootes PM, Mintrop A, Nadeau MJ. 2001. Chemical removal of conservation substances by "Soxhlet"-type extraction. Radiocarbon 43:229-37.

Burgio L, Clark RJH. 2001. Library of FT-Raman spectra of pigments, minerals, pigment media and varnishes, and supplement to existing library of Raman spectra of pigments with visible excitation. Spectrochimica Acta Part A: Molecular and Biomolecular Spectroscopy 57:1491-521.

Caforio L, Fedi ME, Mando PA, Minarelli F, Peccenini E, Pellicori V, Petrucci FC, Schwartzbaum P, Taccetti F. 2014. Discovering forgeries of modern art by the C-14 Bomb Peak. European Physical Journal Plus 129.

Carlyle L. 2001a. MOLART Fellowship, Historical Reconstructions of Artist's Oil Paint: An Investigation of Oil Processing Methods and the Use of Medium-modifiers. Report No. 72894. Ottawa: Canadian Conservation Institute.

Carlyle L. 2005. De Mayerne Programme HART Report 2002-2005. The historically accurate reconstructions techniques project was hosted by The Netherlands Institute of Cultural Heritage (ICN) and supported by the Netherlands Institute for Atomic and Molecular Physics (FOM-AMOLF) and the Canadian Conservation Institute (CCI). Available from FOMAMOLF, ICN and CCI.

Carlyle LA. 2001b. The Artist's Assistant: Oil Painting Instruction Manuals and Handbooks in Britain 1800-1900, with Reference to Selected EighteenthCentury Sources. Archetype Publications.

Eastaugh N. 2008. Pigment Compendium: A Dictionary and Optical Microscopy of Historical Pigments. Routledge.

Fahrni SM, Wacker L, Synal HA, Szidat S. 2013. Improving a gas ion source for C-14 AMS. Nuclear Instruments \& Methods in Physics Research B 294:320-7.

Favaro M, Guastoni A, Marini F, Bianchin S, Gambirasi A. 2012. Characterization of lapis lazuli and corresponding purified pigments for a provenance study of ultramarine pigments used in works of art. Analytical and Bioanalytical Chemistry 402: 2195-208.

Fedi ME, Caforio L, Mando PA, Petrucci F, Taccetti F. 2013. May C-14 be used to date contemporary art? Nuclear Instruments \& Methods in Physics Research B 294:662-5.

Fortunato G, Ritter A, and Fabian D. 2005. Old Masters' lead white pigments: investigations of paintings from the 16 th to the 17 th century using 
high precision lead isotope abundance ratios. Analyst 130:898-906.

Hajdas I. 2008. The Radiocarbon dating method and its applications in Quaternary studies. Quaternary Science Journal - Eiszeitalter und Gegenwart 57:2-24.

Hendriks L, Hajdas I, Ferreira ES, Scherrer NC, Zumbühl S, Küffner M, Wacker L, Synal H-A, and Günther D. 2018. Combined ${ }^{14} \mathrm{C}$ analysis of canvas and organic binder for dating a painting. Radiocarbon 60(1):207-18.

Hendriks L, Hajdas I, McIntyre C, Kuffner M, Scherrer NC, Ferreira ESB. 2016. Microscale radiocarbon dating of paintings. Applied Physics A-Materials Science \& Processing 122.

Hua Q, Barbetti M, Rakowski AZ. 2013. Atmospheric radiocarbon for the period 1950-2010. Radiocarbon 55:2059-72.

Keune K. 2005. Metal soap aggregates in oil paintings from the 15th-20th century. Binding medium, pigments and metal soaps characterized and localized in paint cross-sections: 128-32.

Levin I, Kromer B, Hammer S. 2013. Atmospheric $\Delta^{14} \mathrm{CO}_{2}$ trend in Western European background air from 2000 to 2012. Tellus B: Chemical and Physical Meteorology 65:20092.

Pérez-Villares N, Bailón-Moreno R. 2017. New simple procedure to produce white lead for special use in the plastic arts and in restoration. Journal of Cultural Heritage.

Petrucci F, Caforio L, Fedi M, Mando PA, Peccenini E, Pellicori V, Rylands P, Schwartzbaum P, Taccetti F. 2016. Radiocarbon dating of twentieth century works of art. Applied Physics A - Materials Science \& Processing 122.

Ragai J. 2015. The Scientist and the Forger: Insights into the Scientific Detection of Forgery in Paintings. World Scientific.

Bronk Ramsey C. 2008. Deposition models for chronological records. Quaternary Science Reviews 27:42-60.

Bronk Ramsey C. 2009. Bayesian analysis of radiocarbon dates. Radiocarbon 51:337-60.

Reimer PJ, Bard E, Bayliss A, Beck JW, Blackwell PG, Ramsey CB, Buck CE, Cheng H, Edwards RL, Friedrich M, Grootes PM, Guilderson TP, Haflidason H, Hajdas I, Hatte C, Heaton TJ, Hoffmann DL, Hogg AG, Hughen KA, Kaiser KF, Kromer B, Manning SW, Niu M, Reimer RW, Richards DA, Scott EM, Southon JR, Staff RA, Turney CSM, van der Plicht J. 2013. IntCal13 and Marine13 radiocarbon age calibration curves 050,000 years cal BP. Radiocarbon 55:1869-87.

Ringbom Å, Lindroos A, Heinemeier J, Sonck-Koota P. 2014. 19 years of mortar dating: learning from experience. Radiocarbon 56:619-35.

Roy A. 1993. Artists' pigments. A handbook of their history and characteristics, 2. Washington (DC): National Gallery of Art.

Ruff M, Szidat S, Gaggeler HW, Suter M, Synal HA, Wacker L. 2010. Gaseous radiocarbon measurements of small samples. Nuclear Instruments \& Methods in Physics Research B 268:790-4.

Scherrer NC, Zumbuehl S, Delavy F, Fritsch A, Kuehnen R. 2009. Synthetic organic pigments of the 20th and 21st century relevant to artist's paints: Raman spectra reference collection. Spectrochimica Acta Part a-Molecular and Biomolecular Spectroscopy 73:505-24.

Sedlacek F. 1938. Das Werden des Kärntner Bleiweißverfahrens. Blätter für Geschichte der Technik. Springer. p. 81-91.

Sharma B. 1991. Industrial Chemistry. Krishna Prakashan Media.

Stols-Witlox M, Megens L, Carlyle L. 2012. 'To prepare white excellent...': reconstructions investigating the influence of washing, grinding and decanting of stack-process lead white on pigment composition and particle size. The Artist's Process: Technology and Interpretation. London: Archetype. p 112-29.

Stuiver M, Reimer PJ. 1993. Extended ${ }^{14} \mathrm{C}$ data base and revised CALIB $3.0{ }^{14} \mathrm{C}$ age calibration program. Radiocarbon 35(1):215-30.

Stuiver M, Reimer PJ, Reimer RW. 2018. CALIB 7.1 [WWW program] http://calib.org.

Synal HA. 2013. Developments in accelerator mass spectrometry. International Journal of Mass Spectrometry 349:192-202.

Synal HA, Stocker M, Suter M. 2007. MICADAS: A new compact radiocarbon AMS system. Nuclear Instruments \& Methods in Physics Research B 259:7-13.

Van Strydonck M, Boudin M, Van den Brande T, Saverwyns S, Van Acker J, Lehouck A, Vanclooster D. $2016 .{ }^{14} \mathrm{C}$-dating of the skeleton remains and the content of the lead coffin attributed to the Blessed Idesbald (Abbey of the Dunes, Koksijde, Belgium). Journal of Archaeological Science: Reports 5:276-84.

Wacker L, Bonani G, Friedrich M, Hajdas I, Kromer B, Nemec M, Ruff M, Suter M, Synal HA, Vockenhuber C2010a. MICADAS: routine and high-precision radiocarbon dating. Radiocarbon 52:252-62.

Wacker L, Christl M, Synal HA. 2010b. Bats: A new tool for AMS data reduction. Nuclear Instruments \& Methods in Physics Research B 268:976-79.

Wacker L, Fulop RH, Hajdas I, Molnar M, Rethemeyer J. 2013a. A novel approach to process carbonate samples for radiocarbon measurements with helium carrier gas. Nuclear Instruments \& Methods in Physics Research B 294:214-7.

Wacker L, Lippold J, Molnar M, Schulz H. 2013 b. Towards radiocarbon dating of single foraminifera with a gas ion source. Nuclear Instruments \& Methods in Physics Research B 294:307-10.

Wacker L, Nemec M, Bourquin J. 2010c. A revolutionary graphitisation system: Fully automated, compact and simple. Nuclear Instruments \& Methods in Physics Research B 268:931-4. 